УДК 33

DOI $10.21661 / \mathrm{r}-469371$

\title{
Б. Балевский
}

\section{КОНТРИНДУКЦИЯ И КОНТРДЕДУКЦИЯ В ПРАКТИЧЕСКИХ ЗНАНИЯХ ЭКОНОМИСТОВ О ФЕНОМЕНЕ БЕЗРАБОТИЦЫ}

Аннотация: статья посвящена детальному анализу явления контриндукиии и контрдедукции. Автор статьи обращает особое внимание на необходимость более комплексного исследования феномена безработицьл.

Ключевые слова: безработииа, контриндукиия, контрдедукиия.

\section{B. Balewski}

\section{COUNTERINDUCTION AND COUNTERDEDUCTION IN THE PRACTICAL KNOWLEDGE OF UNEMPLOYMENT PHENOMENON BY ECONOMICSTS}

Abstract: the article is devoted to detailed analysis of the phenomenon of counteriduction and counter-deduction. The author of the article draws special attention to the need for a more comprehensive study of the phenomenon of unemployment.

Keywords: unemployment, counterinduction, counterdeduction.

Modernistic, remote from the epistemology, economic research, produce, mainly, modern, more or less useful instruments - myths. Their creators, probably because of the willingness to coordinate people [Smith A., (1759), transl. Petsch D., (1989), PWN, Warszawa, 7,4,25], become their» (...) prisoners in even bigger degree than our ancient descendants. (...)» [Sedlacek T., (2012), trans. Bakalarz D., (2012), p 122-123].

From time to time, using main methods of knowledge of $20^{\text {th }}$ century philosophy, they slightly transform myths generated before. The activity of a research creator and destructor at the same time should be taken as the myth-creating magic. Such a person becomes who generates the existance in the presence of the studied problems and simultaneously falsifies them, so he acknowledges the existence created by himself 
as the partial non-existence. Approving the «truth» by the mass influences on myth creation. This crowd never reflects in a reliable way the whole population and the most frequently, it desires the bread and the games. The similar myths incubator is used in the concept «scientific research programs» so called apriori division of assumptions and advice on a so called core and safe belt [Balewski B. 2015b, p.87].

As a result, the hope of demythology and necessity of gathering together the most parts of the science, must be focused only in the idea «anything goes» («nothing saint/everything goes»), which constitutes the basis of the theoretical anarchism.

One of its fundamental thesis, saying that ,...) happenings, ways of activity and the results that create the particular scientific fields do not own the common structure (...)", it notices that yesterday constructive procedures do not mean anything today, tomorrow, however, they can be procedures that destroy [Feyerabend P., K., (1975, 1988, 1993) trans. Wiertlewski S., (1996), p. 10].

Moreover, the theoretical anarchism shows that the rejection «non-scientific» ways of knowing the world with the help of argumentation is unfounded. It is impossible to state clearly that science understood as the result of the scientists' work is the only success story. Scientists have also failed. What is more, it cannot be stated that ,(...) the cause of success is the unified procedures (...) because such procedures do not exist (...)" [Feyerabend P., K., (1975, 1988, 1993) transl. Wiertlewski S., (1996), p. 11].

According to Paul Feyerabend «scientists are as architects, creating buildings that are versified with the size and shape that can be assessed after the fact, it means only after they finish their construction. It may be stable or it may fall - you never know. (...)" [Feyerabend P., K., (1975, 1988, 1993) transl. Wiertlewski S., (1996), p. 11$].$ Surely the traditional scientific methods, if they are not directly the source of the destruction for the scientist's work, are the specific «construction that camouflages» nondistant in time the existence disaster created by the basis of their tips.

Science, including its part, that takes care about the unemployment and counteraction of this phenomenon is the anarchistic resolution. If we look deeply into ourselves we will find the proof if this fact not only in the most prominent scientists' resumes. 
Everyone who discovered something (if any), done it defiantly the tradition and traditional thinking. Perhaps, he slotted his discoveries in «previously stated frames» after all. However, their beginning, the beginning of the new knowledge was anarchist. Therefore, for the development of economic research of the unemployment and its counteractions it is worth being in this form of activity, it is worth revealing inside oneself and strengthen the anger against «confirmation condition» that pointlessly assures us , ,...) that the new hypothesis should be confirmed with the acceptable theories (...)" with the simultaneous posing»(...) the threat to the free development of the individual (...)" [Feyerabend P., K., (1975, 1988, 1993) transl. Wiertlewski S., (1996), p. 14]. This praise of freedom is close to the economic doctrine called neoaustrian which preaches the praise of the political freedom (from the system) and «interior» (the extent of directing oneself by the will and not by impulse), is the closest to use of the epistemological compound theory. If there is the convergence of the scientific paradigms between the program of methodological anarchism and neoaustrian school so the inclusion of the instrument of methodological anarchism to exploration of the phenomenon of unemployment is not the action of anarchism itself but only a necessary mitodestructive action.

It should be emphasized that counterinduction is the element of pluralistic methodology so an investigation by the contrast not by the analysis. It is a manifestation of comparing ideas with others and not with the «experience» and improving rather than rejecting the views that «lost» in this «competition».

No displacement of the theory supposedly or even actually if only partially falsified resulted and will result in the emergency of qualitatively different - new knowledge. Surely (...) Such comprehended knowledge does not state the series of internally consistent theories aiming to the perfect description. It is the gradually approach to the truth either. It is rather the constantly enlarging resource of mutually inconsistent, and probably even incommensurable) alternative concepts (...)" [Feyerabend P., K., (1975, 1988, 1993) transl. Wiertlewski S., (1996), p. 29]. Each element of this alternative concept, including theories and fairytales, myths and critical reflections with the necessity of its usage, makes other researchers refine expression and also 
leads to the development of our consciousness and contributes to the enrichment of the culture, as a result of «pulling» into the discussion all of its supporters and opponents.

Counterinduction that points out the non-occurrence of none of the theory complied with all facts, supposes also peculiar «the priority of non-complied hypothesis» with observations, facts and experiences' results. This assumptions lets create the external standard of description (criticism) or even «alternative (fictional) world» which is needed to people,,$(\ldots)$ in order to reveal the features of the real world in which we live - we think (but which could be only the further fictional world) (...)" [Feyerabend P., K., (1975, 1988, 1993) transl. Wiertlewski S., (1996), p. 30].

Counterinduction as the tool of theoretical anarchism and the expression of pluralistic methodology, lets directly accomplish the characteristic for the Austrian doctrine methodological subjectivism as well as antiempirism important for Viennese but also for postmodernism as improving the role of the unit in the scientific process.

The practical combination of counterinduction for the description of the current Polish local or interior market work, will cause generation of resource mutually inconsistent alternative concepts related to the aspect of the efficient state intervention into the labor market. this resource may include in itself the concept of the dipole character (table 1) or of the multi-variant character (table 2).

\section{Table 1.}

The example of the counterinduction usage in the range of issues connected with active efficiency of labor market policy - the perspective of dipole, generated by being based on created with modernist induction «theories» dedicated to the determi-

nant of the active Polish efficient policy of the labor market

\begin{tabular}{|c|c|c|}
\hline $\begin{array}{c}\text { Posi- } \\
\text { tion } \\
\text { number }\end{array}$ & Characteristic of the existing theory & $\begin{array}{c}\text { The opposing counterinductive } \\
\text { hypothesis }\end{array}$ \\
\cline { 2 - 3 } & \multicolumn{1}{|c|}{ Option A } & Option B \\
\hline 1 & $\begin{array}{l}\text { The efficiency of active forms of unemployment } \\
\text { counteraction is determined by: the mark of the lo- } \\
\text { cal development of the technical infrastructure; the } \\
\text { mark of the local entrepreneurship development, } \\
\text { the size and type of unemployment, the effective- } \\
\text { ness of the program's authors and producers, type }\end{array}$ & $\begin{array}{l}\text { There are no economic determi- } \\
\text { nants of the efficiency of the } \\
\text { current active form of unem- } \\
\text { ployment counteraction. }\end{array}$ \\
\hline
\end{tabular}




\begin{tabular}{|c|c|c|}
\hline & $\begin{array}{l}\text { of program, the size of means used for elaboration } \\
\text { and realization of the program, the control of the } \\
\text { program's realization. }\end{array}$ & \\
\hline 2 & $\begin{array}{l}\text { Psycho-social determinants, of the active labor } \\
\text { market policy's efficiency, are basis for the own } \\
\text { education and learning; the level of qualifications } \\
\text { of activated unemployed and the program's pro- } \\
\text { ducers; basis towards the work; preferred aims and } \\
\text { life and vocational values; the level of the social } \\
\text { capitol development in the area: culturally condi- } \\
\text { tioned values and the behavior standards of the } \\
\text { participants and producers of the program; the or- } \\
\text { ganization culture created in the program frame. }\end{array}$ & $\begin{array}{l}\text { There are no psycho-social de- } \\
\text { terminants of the efficiency of } \\
\text { the current active form of unem- } \\
\text { ployment counteraction. }\end{array}$ \\
\hline 3 & $\begin{array}{l}\text { The observed lack of coherence between aims of } \\
\text { the state apparatus and the beneficiaries' aims of } \\
\text { the active form of unemployment counteraction is } \\
\text { the barrier of its efficiency }\end{array}$ & $\begin{array}{l}\text { There is the coherence between } \\
\text { aims of the state apparatus and } \\
\text { the beneficiaries' aims of the ac- } \\
\text { tive form of unemployment } \\
\text { counteraction. }\end{array}$ \\
\hline 4 & $\begin{array}{l}\text { The used measures of the program efficiency of } \\
\text { the vocational activation of the unemployed does } \\
\text { not fully illustrate the processes that are on the la- } \\
\text { bor market. }\end{array}$ & $\begin{array}{l}\text { The used measures of the pro- } \\
\text { gram efficiency of the voca- } \\
\text { tional activation of the unem- } \\
\text { ployed fully illustrate the pro- } \\
\text { cesses that are on the labor mar- } \\
\text { ket.. }\end{array}$ \\
\hline
\end{tabular}

Source:[ Balewski B. (2015b, s. 94]

Multi-dimension of the issues approach with the use of the theoretical anarchism tool, is used for the knowing aspect and even greater enrichment of human culture. It contributes to the development of our consciousness and to enrich our culture as a result of inclusion in the debate a wide range of experts in the knowing field (studying) issues - the aspect of the effectiveness of the active labor market policy. Additionally, it shows directly the space for generating the own, whole, ordered concepts, including the concepts that opt for the state presence in the labor market (even this ineffective one) and the libertarian concepts (por. Table-Option 5).

Table 2.

The example of the counterinduction usage in the range of issues connected with the active efficiency of labor market policy - multi-dimensional aspect generated by being based on created with modernist induction «theories» dedicated to the determinant of the active Polish efficient policy of the labor market 


\begin{tabular}{|c|c|c|c|c|}
\hline $\begin{array}{c}\text { Option } \\
\text { A }\end{array}$ & $\begin{array}{l}\text { Option } \\
\text { B }\end{array}$ & Option 3 & Option 4 & Option 5 \\
\hline $\begin{array}{c}\text { Position } \\
1\end{array}$ & $\begin{array}{c}\text { Position } \\
1\end{array}$ & $\begin{array}{l}\text { It is hard to know } \\
\text { clearly the economic } \\
\text { determinants of effi- } \\
\text { ciency of the current } \\
\text { active form of un- } \\
\text { employment coun- } \\
\text { teraction. }\end{array}$ & $\begin{array}{l}\text { The state is sover- } \\
\text { eign and it is unjusti- } \\
\text { fied to measure and } \\
\text { study the determi- } \\
\text { nant of activities un- } \\
\text { dertaken on its be- } \\
\text { half by persons rep- } \\
\text { resenting the state. }\end{array}$ & $\begin{array}{l}\text { The state presence in } \\
\text { the economy is un- } \\
\text { needed due to the } \\
\text { fact that it limits the } \\
\text { person's freedom. It } \\
\text { should aim to switch } \\
\text { off the state pres- } \\
\text { ence in the econ- } \\
\text { omy, not to search } \\
\text { economic determi- } \\
\text { nants its intervention } \\
\text { in the labor market. }\end{array}$ \\
\hline $\begin{array}{l}\text { Position } \\
2\end{array}$ & $\begin{array}{l}\text { Position } \\
2\end{array}$ & $\begin{array}{l}\text { It is hard to know } \\
\text { clearly psycho-so- } \\
\text { cial conditioning of } \\
\text { efficiency of the cur- } \\
\text { rent active form of } \\
\text { unemployment } \\
\text { counteraction. }\end{array}$ & $\begin{array}{l}\text { The state is sover- } \\
\text { eign and there is no } \\
\text { need to measure and } \\
\text { study he determinant } \\
\text { of activities under- } \\
\text { taken on its behalf } \\
\text { by persons repre- } \\
\text { senting the state. }\end{array}$ & $\begin{array}{l}\text { The state presence in } \\
\text { the economy is un- } \\
\text { needed due to the } \\
\text { fact that it limits the } \\
\text { person's freedom. It } \\
\text { should aim to switch } \\
\text { off the state pres- } \\
\text { ence in the economy } \\
\text { not to search outside } \\
\text { economic determi- } \\
\text { nants its intervention } \\
\text { in the labor market. }\end{array}$ \\
\hline $\begin{array}{c}\text { Positon } \\
3\end{array}$ & $\begin{array}{c}\text { Position } \\
3\end{array}$ & $\begin{array}{l}\text { It is hard to know } \\
\text { clearly if there is co- } \\
\text { herence between the } \\
\text { aims of the state's } \\
\text { apparatus and the } \\
\text { beneficiaries' aims } \\
\text { of the active form of } \\
\text { unemployment } \\
\text { counteraction.. }\end{array}$ & $\begin{array}{l}\text { The state's position } \\
\text { switches off the } \\
\text { need to check the co- } \\
\text { herence mark of its } \\
\text { aims with entrepre- } \\
\text { neurs' aims and an- } \\
\text { ther participants of } \\
\text { the process taken } \\
\text { part in the labor mar- } \\
\text { ket. }\end{array}$ & $\begin{array}{l}\text { The aims' realiza- } \\
\text { tion of each person } \\
\text { is overriding. }\end{array}$ \\
\hline $\begin{array}{c}\text { Position } \\
4\end{array}$ & $\begin{array}{c}\text { Position } \\
4\end{array}$ & $\begin{array}{l}\text { It is hard to know } \\
\text { clearly if the used } \\
\text { measures of the pro- } \\
\text { gram efficiency of } \\
\text { the vocational acti- } \\
\text { vation of the unem- } \\
\text { ployed fully illus- } \\
\text { trate the processes } \\
\text { that are on the labor } \\
\text { market. }\end{array}$ & $\begin{array}{l}\text { The state activity is } \\
\text { not measured. }\end{array}$ & $\begin{array}{l}\text { Using any measures } \\
\text { of intervention effi- } \\
\text { ciency in the labor } \\
\text { market is the action } \\
\text { that masks time uni- } \\
\text { versal the state wast- } \\
\text { age. }\end{array}$ \\
\hline
\end{tabular}

Source: [Balewski B.(2015b), p.95-96] 
Simultaneously, achieved, elaborated the set of results of the pluralist methodology usage states the sign of independence from the arbitrary will of the researcher.

Another instrument that strengthens this independence might be the author's concept known as counterdeduction. It depends on noticing the existence, or creating by oneself, in the earlier phase of the study, the theory based on the deduction with the reference to (or without) so called «universal theories» and resulting on its basis. In that way in order to generate the finding or contrary findings. The product or products of such inference should be taken under social discussion, focused on giving the material that enriches the another new findings related to the aspect covered by the primary deduction (drawing 1 ).

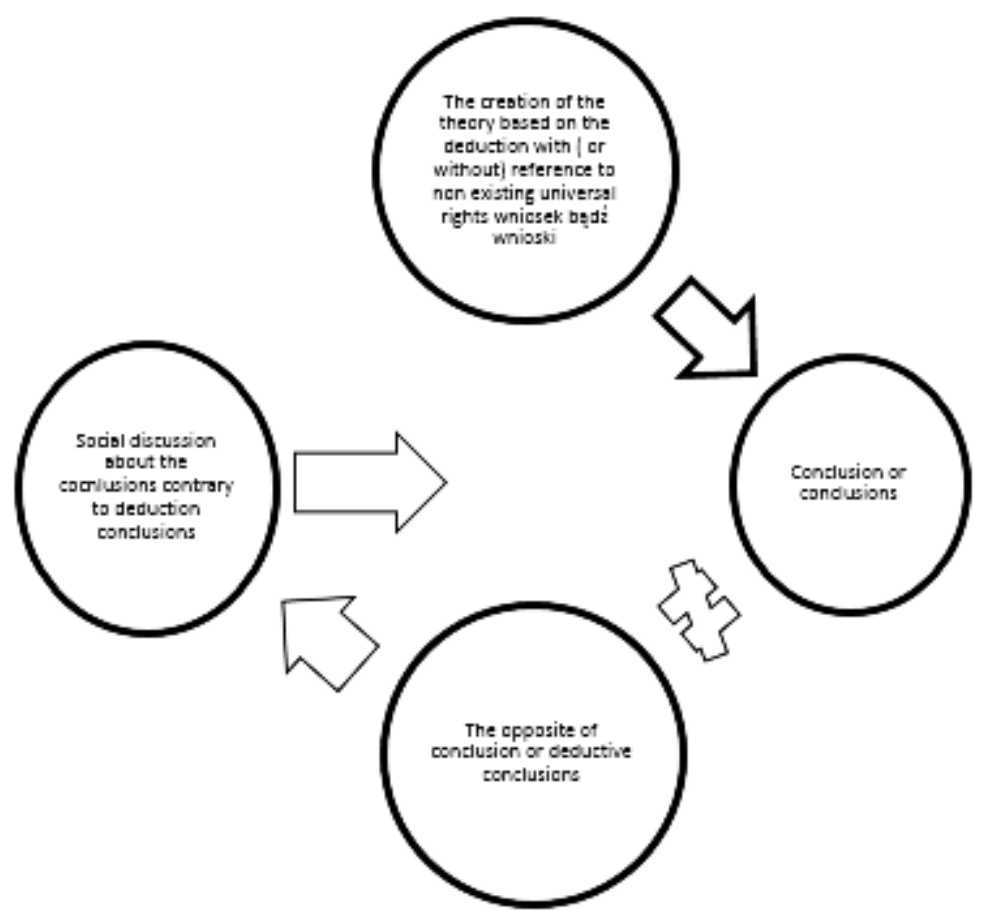

Drawing 1. Assumption to counterdeduction

Source: own elaboration

Created by the author the counterdeduction method derives from the counterinduction theory and it is the proposal of the social discourse over the contr-results of deduction based on mostly, so called, universal rules.

The practical usage of counterdeduction allows, among others, deriving from epistemology achievements, to use for the prediction created earlier the theory 
of the impact of microeconomic, neoclassical theory of migration on observed, in some periods short rank of verifiability of the Philips's curve (drawing 2).

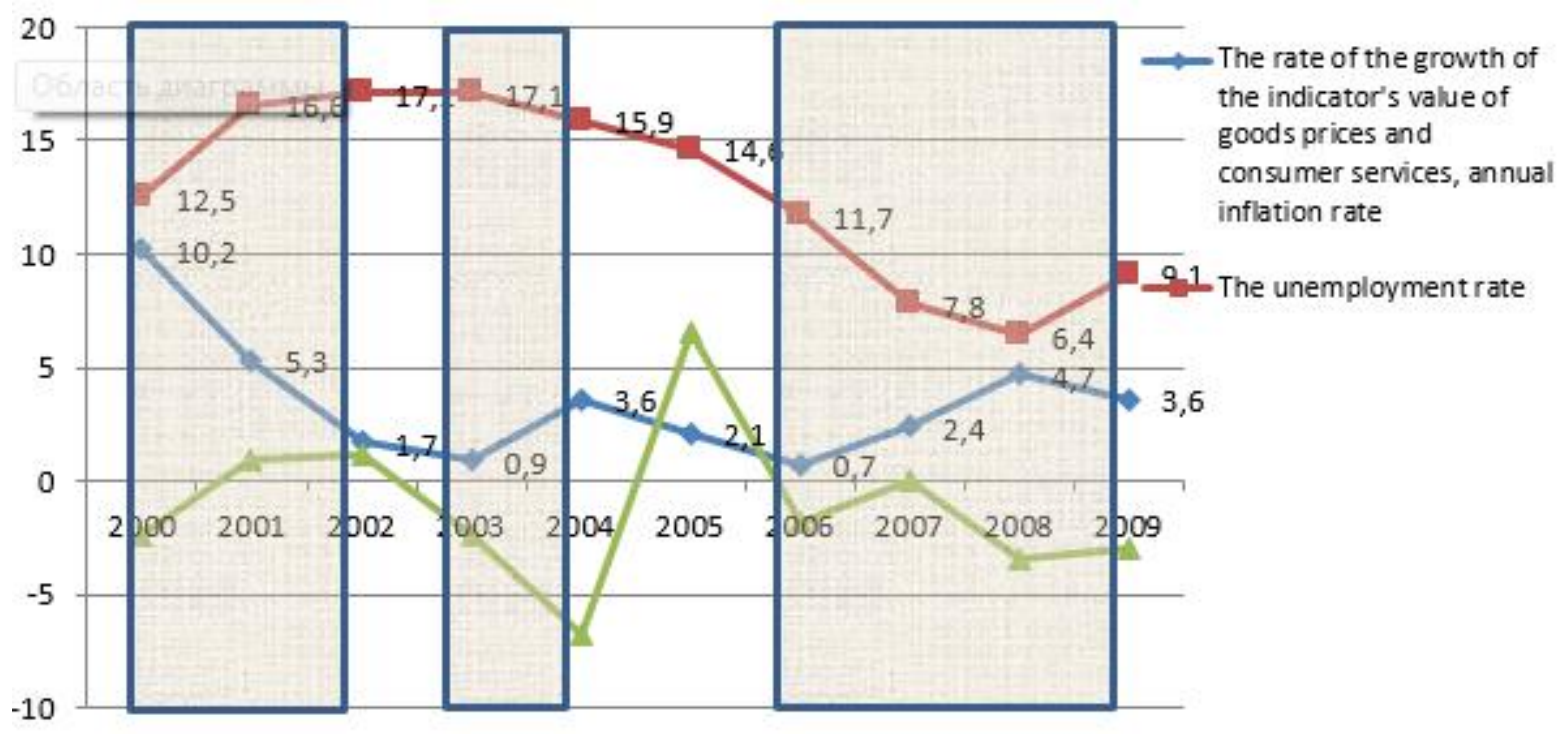

Drawing 2. The relations of the speed growth of the indicator values of the goods prices and the annual inflation rate change in (w \%) the average number of persons in the household in Wielkopolska year 2000-2009

Source: [Balewski B. (2014)]

The deductive, modernist explanation of relations led, by autonomic units of the search of the maximum usage of embodied capitols in them, to the value relations of the inflation size and the value of the unemployment's indicator, is not, however, the symptom of the objective of the unemployment phenomenon's economic knowledge. Firstly, because of the fact that the researcher subjectively compared the analyzed by himself categories, secondly, because he excluded the existence of the other determinants influence. Thirdly, because, the eventual influence of «minds migration» on diminishing of unemployment on the Polish labor market was perceived only in 10 per cent of the period taken in the analysis.

Therefore, the deductive finding, taken from this theory, indicating supposedly the higher level of «minds migration» was accompanied by lower unemployment on the primary labor market and the greater chance to gain the worksite by each of the other participants of the processes undertaken on the Polish labor market, should be said to be the premise for the contr-finding. It might be the statement indicating that 
«minds migration» and the growth of the inflation indicator does not diminish the unemployment rate because the demand on the basic goods is diminished, to which we need the work to have them - the good of the second row. According to the program's assumptions of the methodological anarchism such a contr-finding does not constitute the theory. It is only the premise for the social discourse. In its effects, another premises may appear for primary inference, and further to the contr-finding. These ones might, eventually, be used for the single prediction (drawing 3).

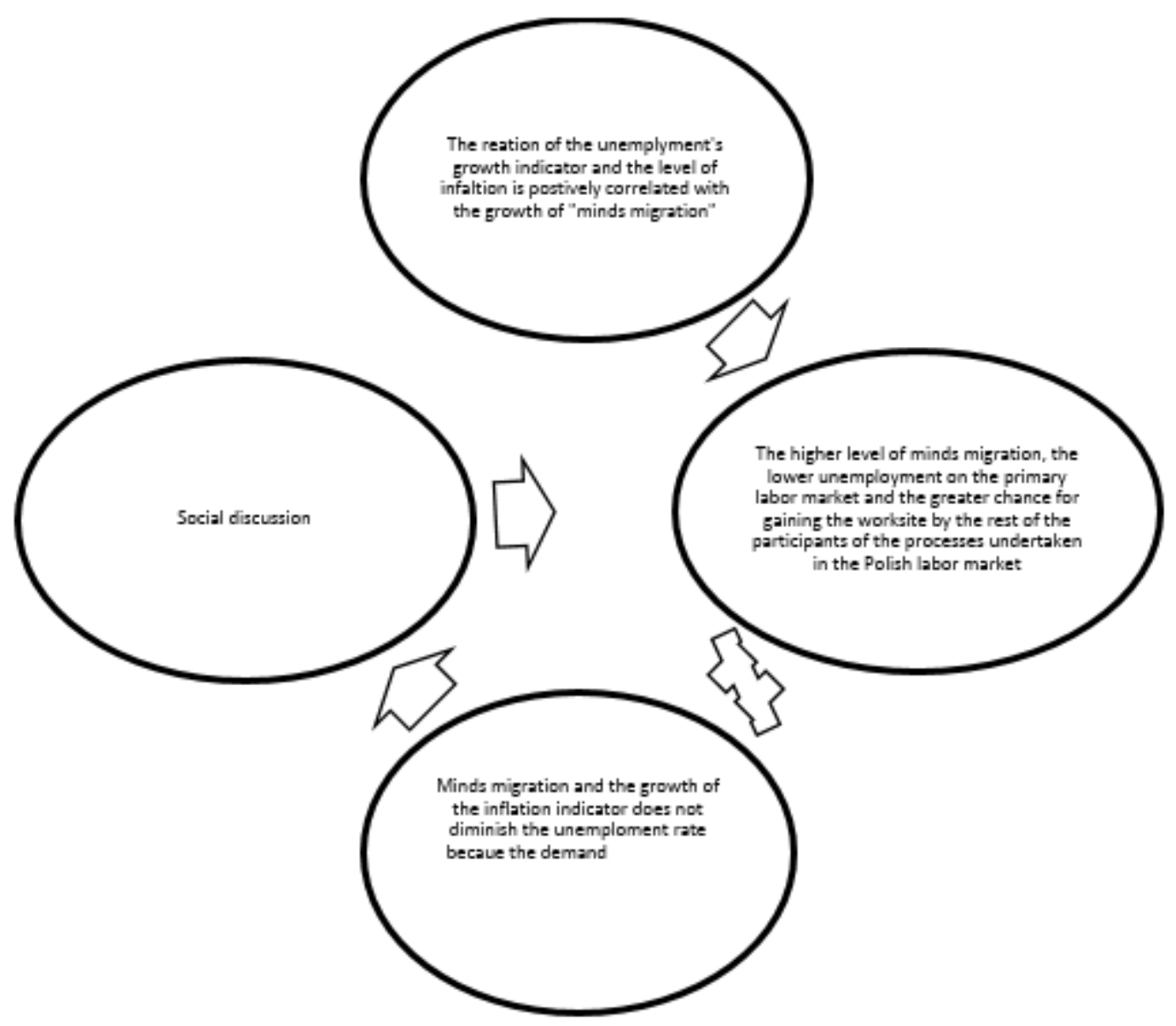

Drawing 3. The example of counterdeduction in the economic research frames of unemployment and counteraction of this phenomenon.

Source: own elaboration

Counterdeduction, therefore, introduces the new element for knowing the unemployment and the counteraction of this phenomenon. It enriches the culture because the discourse over the known issue may state the single, non-imperative prediction made with the knowledge. Simultaneously, together with the whole program of the methodological anarchism, counterdeduction efficiently resists to the potential 
accusation for being the element of the journalism and not constituting the element of the «real science». Firstly, because the epistemology shows that the objective knowledge, mainly this one led in the social science frames, is possible only the frames of compromise that uses the double strategy, that allows the knowledge that is objective but also subjective,but occurring not together but in the various contexts. Secondly, because the inclusion for the «science» category is subjective by itself and mainly based on promythical attitude of the subject classifier and the range of knowledge.

Балевский Блажей - д-р экон. наук, проректор Высшая школа педагогики и технологии в Конине, Польша, Конин.

Balewski Blazhej - doctor of economic sciences, vice-rector at the Higher school of pedagogics and technology in Konin, Poland, Konin. 